evolution. A year of chemistry and physics might be interpolated before physiology. With older and cleverer pupils pure nature-study methods become insufficient. As the mind matures it must have more solid matter to digest. The theory of evolution was beyond the grasp of any but the best class. Prof. Hickson agreed that the ordinary course of biology was unsuitable for schools, but possibly best for the teachers. Prof. Marcus Hartog advocated accurate detailed descriptive and systematic work in botany as the renedy for a certain fluffiness of observation and description in nature-study.

The report on curricula deals in the first instance with boys' schools. The girls' schools had their turn when Prof. H. E. Armstrong addressed the section on The Need of a Scientific Basis to Girls' Education from a Domestic Point of View. Women should cease from competing with men to the neglect of their own interests and natural duties. A scheme of scientific education for girls might radiate from the household. Instead of chalk and salt, the common materials of the household, flour, starch, coal, meat, sugar, \&c., might be used as starting points for a girl's study of science. The science of breadmaking would lead to a general cooperation of all studies helpful to that end. The committee of Section $\mathrm{L}$ would like Prof. Armstrong's paper to have been published in full. It was a powerful enforcement of ideas advocated by Prof. Smithells in York.

The remaining hours were devoted to a discussion on Types of Specialised Teaching. Mr. J. H. Hawthorn, of Leicester, spoke on the teaching and the teacher in evening technical schools. The type of evening student has been changing, there are fewer adult workmen, and the average age is lower than ten years ago. No student should take a trade class until he has laid a foundation of pure science. Good results were obtained by a science teacher with a competent artisan demonstrator. The teacher keeps abreast of the trade when he is known to local factory owners, appreciated by them, and encouraged to visit factories. Mr. C. T. Millis, of the Borough Polytechnic spoke on problems of trade education considered in relation to our school system. Reforms are needed in our elementary-school education to make it an effective preparation for the battle of life, especially for those children who will take up industrial work. Too much attention has hitherto been given to those going into clerical occupations. The types of schools required are specialised trade schools for boys and girls of fourteen to sixteen years of age teaching definite trades, and also preparatory trade schools teaching practical mathematics, drawing, and science. The course must be planned to fit the elementary school at one end, and also to fit the system of apprenticeship followed in each trade. The labour market must be watched to guard against mistaken specialisation. The teacher of trades must have had trade experience in the factory. Cooperation of parents, teachers, employers, and trade-union leaders was necessary. Mrs. J. Ramsay Macdonald described the day trade schools for girls in greate detail. Women's work is double, wage-earning in factory and responsibility at home. To look upon the former as unimportant is disastrous to women wage-earners. There are now day classes in waistcoat-making, dressmaking, corset-making, and ladies' tailoring. The pupils mostly hold scholarships with maintenance grants. Six half-days are devoted to trade teaching, four half-days to general instruction. The trade teachers have come straight from good positions in the workroom. The pupils' development, not customers' convenience, is the first consideration.

An excellent paper on technical training of the rank and file, by Mr. J. C. Legge, of Liverpool, was in reserve, but under pressure of time and in his regretted absence it was distributed in abstract and taken as read.

It was most gratifying to have so good a discussion on these matters of technical and industrial training, which have been a special interest to the president, Sir Philip Magnus. Although not referred to in Section L, no account of technical education at the British Association would be complete without mention of Prof. S. P. Thompson's suggestions in Section G for the abolition of premium apprenticeship, and the opening of the best opportunities in engineering works to merit and not to wealth. From

$$
\text { NO. I976, VOL. 767 }
$$

Section D we cull ancther pregnant idea. The little procession of blue-eyed and brown-eyed school children brought by $\mathrm{Mr}$. Hurst from Burbage inevitably suggests the possibility of our pupils having Mendelian minds as well as Mendelian eyes.

The brief interim report on the conditions of health essential to the carrying on of the work of instruction in schools, presented by Sir Edward Brabrook, may seem inadequate to represent the interest of the association in such matters. But papers on school hygiene were deliberately avoided this year as the most effective method of supporting the simultaneous congress in London.

Two exhibitions were organised, one an exhibition of work representing practical and observational studies collected from the Leicester Council Schools by $\mathrm{Mr}$. Charles Bird. The exhibition of school-science apparatus collected from several important schools by Mr. R. E. Thwaites was conveniently adjacent to the section room.

H. R.

\section{LOCAL SOCIETIES AT THE BRITISH ASSOCIATION.}

THE number of delegates from the local scientific societies which are inf correspondence with the British Association was conference held duripg the Leicester meeting. Mr. H. J. Mackinder opene fussion, in the council chamber of the manicipal, bflings, by an address on the advancement ofd fraphical science by local scientific societies. He ppinted out that in France there are about twenty local societies devoted to geographical study, each taking a region nearly corresponding with one of the old provinces, whilst in Germany there are many societies working specially for the furtherance of local geography. In this country each provincial scientific society should seek to correlate, from a geographical point of view, al the facts obtained by specialists in its own locality, taking as a basis a natural area rather than a county boundary. From such correlation, if andertaken by a person of special training, deductions could be drawn which would be of great value to specialists in the future. Until systematic work of this kind is accomplished on uniform principles throughout the country, no complete geographical conception of our land is possible. Captain Dubois Phillips, representing the Liverpool Geographical Society, referred to the stimulus which should be given to the rational study of geography by local societies through the influence of the British Association; and Dr. H. R. Mill botre testimony to the inspiriting character of the discourse, but feared that the complete realisation of Mr. Mackinder's scheme must be far distant.

At last year's conference of delegates it was suggested that the British Association should be asked to appoint a committee to organise a general photographic survey of the country, county by county. The suggestion was carefully considered by the Corresponding Societies Committee, but it was felt that the scheme was too vast to be taken up by the British Association. At the same time, it was considered that some section of the suggested work, such as archæology, might perhaps be advantageously undertaken. A discussion was therefore initiated by the Rev. R. Ashington Bullen, who read a paper at the Leicester conference on the advisability of appointing a committee for the photographic survey of ancient remains in the British Islands. The anthropological section held, however, that such work might be fairly undertaken by the committee which already exists for the collection and registration of anthropological photographs. As the result of much discussion the following resolutions, on the motion of $\mathrm{Mr}$. W. Jerome Harrison, of Birmingham, were sent up to the Committee of Recommendations and ultimately referred to the Council :-That it is advisable to obtain information as to the present state of things in Britain, in connection with photo-survey work; to publish instructions, or give advice, for the execution of a scientific photographic survey; and to endeavour to found or promote a photo-record of the town and district in which the British Association holds its annual meetings.

At the second meeting, presided over by the Rev. J. O. Bevan, the local societies were urged to give greater 
attention to the study of the funsi occurring in their districts. The subject was introduced by $\mathrm{Mr}$. Carleton Rea, of Worcester, at the instance of the British Mycological Society. It was pointed out by Mr. Rea that British botanists generally omit fungi from the county floras, or give lists that are compiled without the necessary local knowledge. Yet the group ill deserves neglect, for it is one of great economic importance. It is said that the cereal rusts cost Prussia in one year 20,900,00ol. To encourage the study of British fungi, the Woolhope Naturalists' Club in ' 1868 instituted a series of autumnal forays, and some other natural-history clubs, like the Essex Field Club, have followed the example; but this occasional study is insufficient. The fungi should be studied throughout the year, and specimens displayed for exhibition at all times in the society's rooms or in the local museum. In the course of the discussion, Prof. J. W. Carr, of Nottingham, and some other naturalists, dwelt on the difficulty of working out the fungi of a given district in consequence of the general lack of expert knowledge. Mr. Rea, however, considered it the duty of each society to be able to determine the fungi of its own area, without submitting them, except in difficult cases, to a mycological referee. A large collection of handcoloured photographs of fungi, taken by $\mathrm{Mr}$. A. Wallis, of Kettering, was exhibited by Mr. H. N. Dixon.

Several delegates from the sections explained in what way the local scientific societies might aid the sectional committees. Mr. Wilfrid Mark IVebb appealed for specimens of centipedes in illustration of a work on which he was engaged, but the Rev. Thomas Stebbing explained that his repeated request for well-shrimps had met with no response from any of the local societies through their delegates.

\section{HEALTH AND EDUCATION.}

THE Health Education League of Boston, Massachusetts, U.S.A., has issued a series of small pamphlets dealing with the common aspect of our daily life from a health point of view. Mrs 1 . Richards appears to be the moving sp/rit in thy tseful sanitary campaign, and directors of the lesie several medical men. The usefulness of the hives contained in these tiny publications is undoubted. all the more so because they are tiny, and because fe facts they set forth are stated in terms readily to be understood by everyone.

The first of the series gives "Hints for Health in Hot Weather." In it we find sensible remarks, under the heading of "Rules for Children," "Cleanliness," \&c., concerning the general bringing up of children, but, except the benefits of sunshine and the use of wire screens to keep out mosquitoes, we are told all too little about bodily protection in hot weather.

No. 2 of the series deals with milk. The story of milk as a food and as a vehicle of disease is admirably told. The meaning of unwholesome milk, how it is brought about, and how prevented by chilling and sterilising, is described and fully explained; the information contained in this pamphlet is an education to the public in the very best sense.

"Colds and their Prevention" is dealt with in series No. 3. Under this heading the subject of ventilation is skilfully introduced. The care of the skin and of the feet is also incorporated in the text.

No. 4 of the series is concerned with "Meat and Drink." Good nutrition is held to be of vital importance to our courage, cheerfulness, and physical efficiency, and the meaning of cooking and the effects of boiling, roasting, frying, \&c., scientifically yet simply explained.

"Healthful Homes" is the subject of No. 5. The moral atmosphere of family life is dwelt upon as an important factor in national life, and the practical details of elementary hygiene and sanitation are here collected and set forth in admirable fashion.

"The Successful Woman" (series No. 6) pamphlet tells the business woman how to keep well, and good and sensible rules and suggestions are laid down for her guidance. Most of us would hesitate to stamp a business No. I976, vกI. 76$]$ woman, that is, one whose chief ideal is to keep well, so " that she may earn a full salary," as one of nature's successful productions. That women should be compelled to, or by choice, take to business cannot but be regarded as one of the blots of our civilisation of which we ought to be heartily ashamed. To stamp a woman so engaged as a successful woman is rather encouraging woman along a side-path of doubtful benefit to the racc.

"The Boy and the Cigarette" (series No: 7) should be read by everyone, and the recommendations against this poisonous and harmful practice should be stringently enforced by law in the case of boys. Women are warned that neither their brothers nor their admirers think better of them for smoking cigarettes. A woman who smokes is spoken of in a ribald manner, did women but know it, by men in private, and their morality made a subject of question and banter.

"The Care of Little Children" (series No. 8) is replete with good advice, and can be heartily commended; and the fact that the future health and welfare of the individual is mostly determined by the wisdom or folly bestowed upon the infant during the first few weeks of life pointedly brought home.

"The Plague of Mosquitoes and Flies" constitutes the subject of series No. 9. It is a timely contribution, and contains the most recent lessons we have learned concerning the spread of disease. We know within recent years that our household pests and pets, the flies, fleas, bugs, and other vermin which inhabit our houses, and our dogs, cats, fowls, mice, rats, \&c., are frequent media of the transmission of diseases. It is a great advance in knowledge, one of the greatest hygienic advances since Parker first brought the subject systematically before the world. This pamphlet should be distributed broadcast, and the subject it deals with taught in every school.

No. II of the series points out, under the title of "Tonics and Stimulants," the necessity for temperance in the use of alcohol, tea and coffee, and drugs. The lessons in this short pamphlet are well taught, and the advice wise and wholesome.

The series as a whole is an unfortunate necessity. It implies that mankind, in modern days, has so lost touch with nature and nature's ways that the instinct of the care of the young, which belongs in common to all animals, is a lost attribute of modern men and women. Perhaps it is wise to recognise the fact; and being recognised, we can conceive no better method of repairing the loss than by the publication and wide distribution of information such as we find in the series before us.

THE INSTITUTION OF MINING ENGINEERS

THE annual meeting of the Institution of Mining Engineers, held at Sfeffield on September 4, 5, and 6 , was $7^{\text {ttended by }}$ large number of members. Cordial addyesses of wy come were delivered by Mr. J. R. R. I son, int of the Midland Institute of Mining En in eers by the Lord Mayor of Sheffield, and by Mr. A. J. Alobson, speaking on behalf of the Chamber of Commerce and of Sheffield University, who kindly lent the Firth Hall for the occasion. Mr. C. E. Rhodes was elected president for the ensuing year, and the report of the council, read by the secretary, Mr. M. Walton Brown, recorded a year of satisfactory progress. The institution is a federation of seven local mining societies, and its membership has grown from 1239 since the foundation in 1889 to 3100 at the present time. During the past year sixty-eight papers of a varied nature were published in the Transactions. Mention was made of the efforts being made, in conjunction with the British Science Guild, to secure a reduction of postage on the publications of scientific societies, and of the reports submitted by Mr. J. A. Longden, representative of the institution at the British Association, and by Mr. Bennett H. Brough, representative of the institution at the testing congress in Brussels. It was also noted that Mr. Arthur Sopwith, senior past-president, represented the institution on the governing body of the Imperial College of Science and Technology.

Three papers were read and discussed. The first, by Mr. J. W. Fryar and Mr. Robert Clive, described the 